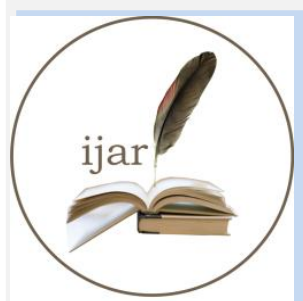

ISSN NO. 2320-5407

\section{Journal Homepage: - www.journalijar.com INTERNATIONAL JOURNAL OF ADVANCED RESEARCH (IJAR)}

Article DOI: $10.21474 / \mathrm{IJAR01/1434}$

DOI URL: http://dx.doi.org/10.21474/IJAR01/1434
INTERNATIONAL JOURNAL OF ADVANCED RESEARCH (JJAR)

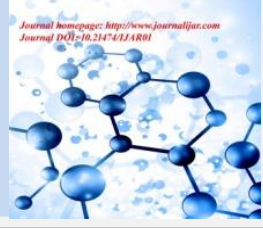

RESEARCH ARTICLE

\title{
PATHOGENICITY EFFECT OF THE ENTOMOPATHOGENIC NEMATODE STEINERNEMA SPP. (RHABDITIDA: STEINERNEMATIDAE) AS BIOLOGICAL CONTROLOF SCYPHOPHORUS ACUPUNCTATUS, PEST OF AGAVE TEQUILANA WEBER.
}

Eva Judith Hueso Guerrero ${ }^{1}$, Patricia Stock ${ }^{2}$, Jalil Fallad Chávez ${ }^{1}$ and Mancilla Villa OscarRaul ${ }^{1}$.

1. Universidad de Guadalajara, Centro Universitario de la Costa Sur, Jalisco, México. Tel: 3173825010 ext. 57134.

2. Department of Entomology, Universidad of Arizona, Forbes 410, PO Box 210036, Tucson, AZ, USA.

\section{Manuscript Info}

Manuscript History

Received: 12 June 2016

Final Accepted: 19 July 2016

Published: August 2016

Key words:-

Steinernema riobrave, picudo negro, Agave tequilana.

\section{Abstract}

The weevil Scyphophorus acupunctatus(Gyllenhal), is a insect pest attacks the Agave tequilana. The damage is due to larvae bore into the stem forming galleries and feeding on it as the root of the agave, to avoid the effects of environmental pollution caused by chemical insecticides, some studies suggest the search for alternatives as the use of biological control by of entomopathogenic nematodesapplication.In the present study, entomopathogenic nematode isolateswere found on dead larvae weevil as well in adults. The molecular and phylogenetic comparative analysisstudies, showed that all three native isolates were identified as members of the Steinernema riobrave.Likewise, EPNpathogenicity of against the weevil was quantified, considering the criterion of overlapping fiducial limits and $\mathrm{CL}_{50}$ was determined that the weevil larvae have increased susceptibility for the isolateSteinernema sp. AN4, Steinernema sp. AN2 and exotic strain $S$. carpocapsae All (Florida) that had a lower $\mathrm{CL}_{50}$, besides not present significant differences between them. This findings had determined the effect of exotic strain as well native isolate, which showed to have potential on the use as biocontrol forS. acupunctatuslarvae.

Copy Right, IJAR, 2016,. All rights reserved.

\section{Introduction:-}

The agave weevil Scyphophorus acupunctatus(Gyllenhal), is an insect that attacks the Agave tequilanaplant whereas tequila is made. Weevils' damage are located at the bottom of the plant, either in the bud, leaves, head and/or root. The larvae bore forming stalk galleries and feeding out from the root of the agave plant. From a studyconducted by Solis,regarding plants' damages, the results suggest this pest might cause up to $24.5 \%$ of the volume of damaged agave head in the state of Jalisco, Mexico (Solis et al., 2001).

Since the 70's, this weevil is been reported on Sisal (Agave sisalana)and Henequén (Agave fourcroydes Lem.)plants (Hopkinson \& Maseru, 1970). Another study reports that at the same timethat $A$. tequilanawere introduced at the State of Morelos, Mexico, black weevil populations infesting the cropsand were reported up to 100 insects per plant. 
The insecticide applications costs were estimated between $50 \%$ to $60 \%$ of cost production(Valdes, 2002). In the North of the State of Yucatan, Mexico, have been reported production losses were calculated as $40 \%$ in plantations A. fourcroydes Lemaire (EPPO, 2002).

In order to avoid environmental pollution effects on crop fields caused by commonly used of chemical insecticides in controlling insect pests Gaugler (1981) suggestsan integrated pest managementapproach by including the use of biological control that includes microorganisms application such as fungi, viruses, bacteria and entomopathogenic nematodes (EPN). The latter have proven their pathogenicity against larvae and pupae of "Curculionidae" Gaugler (1988). The use ofEPN is recommended because they may carry out an equivalent effectof a chemical insecticide. The insect is parasitized by EPN, and dies quickly;on the next 48 hours. Others qualities are that they have the abilities to find the host, and a good persistence in their natural environment, and compatible with chemical and biological insecticides also can be artificially multiplied on a large scale in liquid or solid media and can be stored for long periods of time under refrigeration. Even more, EPN can be applied by conventional methods of crop's irrigationsystems (Kaya \& Gaugler, 1993). Results of studies reported by Poinar (1979) and Kaya (1990) show that steinernematids and heterorhabditids EPN are effective against several species of insect pests that live in soil and cryptic hábitats as well. However Simoes \& Rosa (1996) reports difference in virulence patterns fromnematodes towardssome insectswhen EPNspecies or strains are compared among them. This results are evidence that highlights the need for more studies in order to identify those native nematodes with potential for biological control of insect species.

Pathogenicity tests onHeterorhabditis sp., which were been extracted from a body of $S$. acupunctatusadult,have been reported by Velazquez et al. (2006). Another similar study on a native isolated existence on the genreof Steinernema $s p$. larvae of S. interstitialis Gyllenhal was carried out by Aquino et al. (2006). Although, there are few reports of scientific studies in Mexico on the use of EPN in controlling S. acupunctatusweevil larvae, as wellonthe assessment $S$. acupunctatus larvae susceptibility towards exotic strains and native isolates. These studies have contributed on detecting native EPN, their isolation and further identification to specie level by molecular genetic analysis by using the polymerase chain reaction (PCR)molecular technique.

\section{Materials and Methods:-}

Plants that were naturally infested with $S$. acupunctatus were collected from soils of Autlán County, located in the Jalisco N19o 43,735', W104o 20,844' coordinates and 886 m.s.n.m. geographical elevation.Specimens of Agave plants were collected from June to November with ages between 3 to 7 years. The plants that were chopped uppresented the following characteristics: blue/green to purplish/gray, bud fallen and easy release, and/or with the presence of adult weevils on the leaves (Valenzuela, 1997). Weevils larvae were extracted from inside intact stem that were visually healthy, with good mobility, with an average weight of $0.5 \pm 0.1$ grams, with a brain diameter of $0.5 \mathrm{~cm}$, and 18 millimeters long, with cream color and approximately on the fifth instar (Gentry, 1982). The larvae were placed individually in Petri dishes of $60 \mathrm{X} 15 \mathrm{~mm}$ containing a piece of filter paper Whatman No. 1.

During the S. acupunctatus larvae extractionprocess frominside agavehead, all dead larvae identified and separated if they showed common symptoms of natural infestation by EPN such as brown or brown dark, with soft body or presented gummy waste from their natural orifices. These larvae were washed with distilled water to be disinfected and were transferred to the respective White traps (1927) to confirm the EPNinfestation with the emergence of JI (Woodring \& Kaya, 1988).

Isolates were nominated as Steinernema $s p$. AN1, Steinernema $s p$. AN2, Steinernema sp. AN3 and Steinernema $s p$. AN4, respectively. Isolates were stored until the application of bioassays against $S$. acupunctatus and $G$. mellonellalarvae.

Isolated Identification:-

In order to identify the EPN isolates is made by taking in account some criteria such asmultifactorial differences amongEPNspecies and primarily based on behavior, infectivity, and host range (Simoes \& Rosa, 1996; Brown \& Gaugler, 1997; Campbell \& Gaugler., 1997; De Doucet et al, 1999 ). Furthermore, molecular techniques are using to detect DNA variations among isolates, strains or different prototypes (Alves, 1986; Reid et al., 1997).

The taxonomic identification was carried out by using the main orders and families identification keys for insect parasitic nematodes. taxonomic key for the genus Steinernema.Subsequently, an analysis of hybrid crosses were 
used to confirm the identificationsof the species (Kaya \& Stock, 1997).

The DNA extraction, PCR amplification of 28S rDNA and the sequencing are the molecular techniques used on native isolates EPNidentification (Hillis \& Moritz, 1996).

For identification of isolates EPNSteinernema from genreto specie level, a DNA sequencing the small subunit of transcription internal space (ITS) region (Reid \&Hominick, 1992) was performed.ADNA library that contentssequensing of more than 20 species of Steinernemawas used as reference (Stock et al., 2001). Sequence analysis was performed using the Sequencher V 3.0 program was used to edit and verify the bases (Gene Codes, Ann Arbor, Michigan).

\section{Susceptibility determination of $S$. acupunctatus based on the Nematodes $\mathrm{CL}_{50}$ :-}

To assess the $S$. acupunctatus larvae susceptibility towards the nematodes, a range of concentrations starting from 2 , $4,8,16,32$, to 64 JIs per larva based on the $\mathrm{LC}_{50}$ was used. In this bioassay,Steinernema carpocapsae All (Florida), Steinernema carpocapsae All (California) strains additionally were evaluated. Out of total of 60 larvae on each concentration, onone milliliter of distilled water, the JI nematodeswere used.Fourgroups of repetitions with 15 larvae each and a control group, were applied (Wilson et al., 1994). Petri dishes were placed in plastic bags to keep moisture and incubated in the dark at a temperature $25^{\circ} \mathrm{C} \pm 1^{\circ} \mathrm{C}$ (Glazer et al., 1991). Larvae mortality was determined every 24 hours over a period of 120 hours (Epsky \& Capinera, 1994). Dead larvae were removed and incubated in White(White, 1927)traps. The weevil larvae susceptibility was determined on the results of the lethal concentration average observed oneach strain and native isolates, and then, were established by Log-Dose-Probit lines (Finney, 1971).

\section{Results:-}

Native Isolates Identification:-

Isolation and identification of nematodes by host morphologic symptoms:-

A total of 70 Agavetequilanaheads were used for larvae extraction.From those heads, 11 dead larvae and adult $S$. acupunctatus were collected from inside theheads. The larvae and adult bodies were transferred in White' traps for infective juveniles emergence. Fromlarvae corpses collected from the four isolates, nematodes were obtained. Three isolates were recovered from larvae and one from adult. The isolates were identified to genre level by the observed symptoms in the host bodies, which showed soft body, color brown and gummy secretions suggesting infestation of NEPs the Steinernema genre. By using molecular techniques was determined that three isolates are belonging to $S$. riobrave and nominated as $\mathrm{SrAN} 1, \mathrm{SrAN} 3$, SrAN4.

\section{Native Isolates Taxonomic Identification:-}

For identification of the natives isolates to genre level,a set of taxonomic keys for orders and families of insect parasitic nematodes (Kaya and Stock, 1997) were used. In addition, all the morphological characteristics presented in both,infective juvenile and adult isolatesstages, were compared.The results showed that they coincided toSteinernema spp. genre, and according to the showedsymptoms on the larvae and adult host bodies, allows to infer that they belong to the same genreSteinernema spp.

Native isolates were identified to especie level onSteinernema speciesandS. riobraveby using taxonomic keys (Cabanillas et al, 1994a; Kaya and Stock, 1997). By Recognizing the four isolatesbelongsto the same S. riobrave EPNespecie. The morphological characteristics description were corroborated with characterization (Cabanillas et al.,1994a). S. riobrave adults have smooth cuticle, rounded head. The excretory pore is usually located in the front of the nerve ring, although sometimes differs. Females are distinguished from males by their vigorous behavior and C-shaped body when they rest. In addition to the first generation they are larger. The vulva is a pronounced transverse opening located on the body surface. In young females tail is shorter than in mature females. Males have thin body and are smaller than females. When they are at rest,they take a $\mathbf{J}$ shape. They do not exhibit bursa, they retain a pair of arcuate spicules, separate but contiguous. The gubernaculum is longer than the spike. They have a small visible mucro on the terminal part of the tail which is typical of the $S$. riobrave.

\section{Cross-Hybridise Test:-}

Cross hybridise for each $S$. riobravespecies and each of three isolates for the natives Steinernema spp. genreAN1, AN3 and AN4 were formed. All pairs generated progeny (Table 1). These results along with the morphological and molecular study indicate that native isolates belong to $S$. Riobrave. 


\section{Molecular identification for species level:-}

The identification of the native isolates that have been obtained from larvae bodies and adult of Scyphophorus acupunctatus was by a molecular study that is belonging to $S$. riobrave. The DNA strand sequence from ITS region of these three isolates was compared with the sequence of $S$. riobrave without presenting difference in the bases. The lengths of the three isolates were sequenced and confirmed to complete $28 \mathrm{~S}$ rDNA partial regions, ITS-1, by aligning with the corresponding sequence of $S$. riobrave. Isolates showed high homology to the known sequence of the ITS region of $S$. riobrave (access number BANK KIT 752643, 765538 and 752645).

All three isolates showed $99.5 \%$ sequencial identity without mutations for the sequence in the studiedregion: $28 \mathrm{~S}$ rDNA, with 841 base pairs. RDNA sequence (841pb) for native isolated Steinernema spp. AN1, AN3 and AN4 were registered in the Gene Bank (GenBank) under the registration number EF100770 as belonging to $S$. riobrave.

\section{Phylogenetic analysis:-}

In addition to the already mentioned studies a phylogenetic analysis of native isolates it was performed(see Figure 1). Whereas genetic affinity is kept in all three native isolates with respect to the observed distance between $S$. riobrave. These results suggest that native isolates of Steinernema sp. AN1, Steinernema sp. AN3, and Steinernema $s p$. AN4 belongs to $S$. riobrave.

\section{Susceptibility Determination of $S$. acupunctatus by the $\mathrm{CL}_{50}$ of nematodes:-}

Susceptibility Determination for weevil larvae was made by considering the virulence assessment obtained through the lethal concentration average $\left(\mathrm{LC}_{50}\right)$ for each strains and the results showed that native isolates selected from the above bioassay that larvae susceptibility was increased. Weevil larvae were susceptible to all strains and isolates native exotic applied. Considering the $\mathrm{CL}_{50}$ and according to the criterion of overlapping fiducial limits values, nematodes were grouped to establish the strain or isolate those has presented more susceptibility towards weevil larvae. In order to determine the susceptibility through the most virulent nematodes are those cases that have required a lower JI concentration. As shown in table 2, nematodes with less concentration in a range of 4.6 to 7.0 were $S$. riobrave AN4, S. riobrave AN2 and S. carpocapsae All (Florida). Followed by S. carpocapsae All (California). Finally the $S$. riobrave AN1 nematode was characterized by manifest as $20.03 \mathrm{CL}_{50}$ (Table 2).

\section{Discussion:-}

Isolation and identification of native isolates:-

The differences among EPN species lie in factors such as behavior, infectivity, host range and tolerance environment. These factors create the need for search and discovery of new strains and potential species for control of insect pests (Simoes \& Rosa, 1996; Brown \& Gaugler, 1997; Campbell \& Gaugler, 1997; De Doucet et al., 1999). Under this framework, the hypothesis of EPN presence on $S$. acupunctatus larvae is valid since they have been isolated and identified to genre level by morphological symptoms observed in the host body and the use of appropriate taxonomic keys to be confirmed genre of Steinernema spp. These symptoms that have showed infected larvae by native isolates coincided as described by Gaugler and Campbell (1990), Poinar (1990), Cabanillas et al., (1994b), and Kaya and Stock (1997). In addition, the JIs that emerged from S. acupunctatus larvae had corroborated Koch's postulates in order to confirm larvae infestation on G. mellonella (Kaya \& Stock, 1997).

Finally, from the results of the molecular study and phylogenetic comparative analysis, all three native isolates were identified as members of the $S$. riobrave specie and corroborated by progeny presence on cross hybrids test for $S$. riobrave. This specie has more potential with respect of exotic strains used. This feature provides a reason for more search of more potential native nematodes that are able to be used as endemic insect pest control (De Doucet et al., 1999; Stock et al., 2001).

However, the obtained results in this study differ from results of some authors for $S$. carpocapsae strain that has been successfully studied in various hosts by some authors (Shapiro et al., 1993). They are reporting S. carpocapsae with great potential on biological control for more than 250 insect pests of various orders. Thus, the $S$. riobrave successed against Anthonomus grandis at all stages with 100\% mortality (Cabanillas, 2003) is also reported. Similarly Ricci et al., (1996) by the application of S. riobrave reported results an equivalent of $100 \%$ mortality in $G$. mellonella larvae. L. It is noteworthy that the host used in that study and used in the other reports by the authors is above mentioned are different and explains the divergence in susceptibility by the host towards the strains $S$. riobrave and S. carpocapsae (Simoes \& Rosas, 1996). 
Susceptibility determination of $S$. acupunctatus against nematodes by using the $\mathbf{C L}_{50}$ ::-

The weevil larvae susceptibility to EPN was quantified by determining the of exotic strains and native isolates effect. Also, the $\mathrm{CL}_{50}$ was estimated in order to eliminate $50 \%$ of the population. Considering the criterion of overlapping fiducial limits and its correspondent $\mathrm{CL}_{50}$, by the results it was determined that weevil larvae have increased susceptibility to isolated Steinernema sp. AN4, Steinernema sp. AN2, and exotic strain of S. carpocapsae All (Florida) that presented a lower $\mathrm{LC}_{50}$. In addition, those EPN have showed not significant differences among them.

The obtained results in this study corroborate those reported by Aquino et al., (2006) about the larvae susceptibility for nematodes $S$. interstitialis and $S$. carpocapsae native isolates in the State of Oaxaca, Mexico. Although, Aquino et al., (2006) methodology differs from the present investigation. The larvae were extracted from the maguey leaves and put into cans 300 milliliters. Each pot was placed two larvae and the larvae fed out from the maguey plant. Right after larae were adapted an treatment was applied which was consisting of the application of 4,500 JI/ml of native isolate. In the present study was used a range from 2 to $500 \mathrm{JI} / \mathrm{ml}$ concentration. However, the concentration differences JI/milliliter for this study found that both, exotic and native strain isolates reach the lethal mortality average in a range from 4.6 to $7.0 \mathrm{JI} / \mathrm{ml} / \mathrm{larvae}$ within five days of exposure; while Aquino et al., reported $100 \%$ mortality of $S$. interstitialis larvae on $S$. carpocapsae strain with a $9000 \mathrm{~J} / /$ larvae concentration for 11 days of infection. Likewise, for the native isolate, these authors reported as unidentified, a $4500 \mathrm{JI} /$ larvae concentration had reached $100 \%$ of mortality at 18 days of infestation. However, the results of both studies are consistent with the potential presented by $S$. carpocapsae native and isolated nematodes as a viable alternative in the Agave weevil control. Likewise, Velazquez et al., (2006) have reported the nematode Heterorhabditis sp. that pathogenicity tests fail to cause mortality in adults of $S$. acupunctatus. In the same way, they reaffirm the importance of the need to search for native nematodes to determine their bio-ecological characteristics as well as its specificity and virulence on insect pests.

\section{Conclusion:-}

The presence of four isolated natives of $S$. riobrave confirms the existence of native EPN in the region Autlán, Jalisco, Mexico. In this waym the hypothesis is accepted on the existence of isolated native EPN associated with adults and larvae weevil of the agave plant. These EPN have the potential to be used as biocontrol on $S$. acupunctatus larvae as they present pathogenicity and virulence like the exotic strain $S$. carpocapsae All (Florida).

Table 1:- Cross hybridise results for Steinernema riobrave and native isolatesSteinernema AN1, AN3 and AN4.

\begin{tabular}{|l|l|l|l|l|}
\hline Specie / isolate & S. riobrave & Steinernema sp. AN1 & Steinernema sp. AN3 & Steinernema sp. AN4 \\
\hline S. riobrave & + & + & + & + \\
\hline Steinernema sp. AN1 & + & + & + & + \\
\hline Steinernema sp. AN3 & + & + & + & + \\
\hline Steinernema sp. AN4 & + & + & + & + \\
\hline
\end{tabular}

+ Presence of progeny (fertile), -Ausence of progeny.

Table 2:- Lethal concentration $\left(\mathrm{LC}_{50}\right)$ determination forNEPs strains and isolates evaluated against $S$. acunpunctatuslarvae.

\begin{tabular}{|l|l|l|l|l|l|l|}
\hline Entomopatogenic Nematode & $\mathrm{CL}_{50 *}$ & \multicolumn{2}{|l|}{ Confidence Interval (95\%) } & $\mathrm{P}$ & $\mathrm{X}^{2}$ & $\begin{array}{l}\text { Probit Squation } \\
\mathrm{Y}=a+b \mathrm{X}\end{array}$ \\
\cline { 3 - 5 } & & Lower & Higher & & & .036 \\
\hline S. riobrave AN4 & $4.60 \mathrm{~A}$ & 2.87 & 6.48 & 10.79 & $\mathrm{Y}=1.00+2.34 \mathrm{X}$ \\
\hline S. riobrave AN2 & $5.70 \mathrm{AB}$ & 4.41 & 7.36 & .129 & 7.25 & $\mathrm{Y}=1.57+0.67 \mathrm{X}$ \\
\hline S. carpocapsae All (Florida) & $7.06 \mathrm{AB}$ & 5.45 & 9.14 & .378 & 3.69 & $\mathrm{Y}=1.35+1.14 \mathrm{X}$ \\
\hline S carpocapsae All (California) & $9.41 \mathrm{~B}$ & 6.80 & 13.10 & .630 & 1.90 & $\mathrm{Y}=1.03+1.94 \mathrm{X}$ \\
\hline S. riobrave AN1 & $20.03 \mathrm{C}$ & 15.15 & 26.48 & .534 & 2.49 & $\mathrm{Y}=1.26+0.83 \mathrm{X}$ \\
\hline
\end{tabular}

Values within the column, followed by the same letter are not statistically different based on overlapping values of the fiducial limits. * Median lethal concentration required to kill $50 \%$ of treated larvae. 


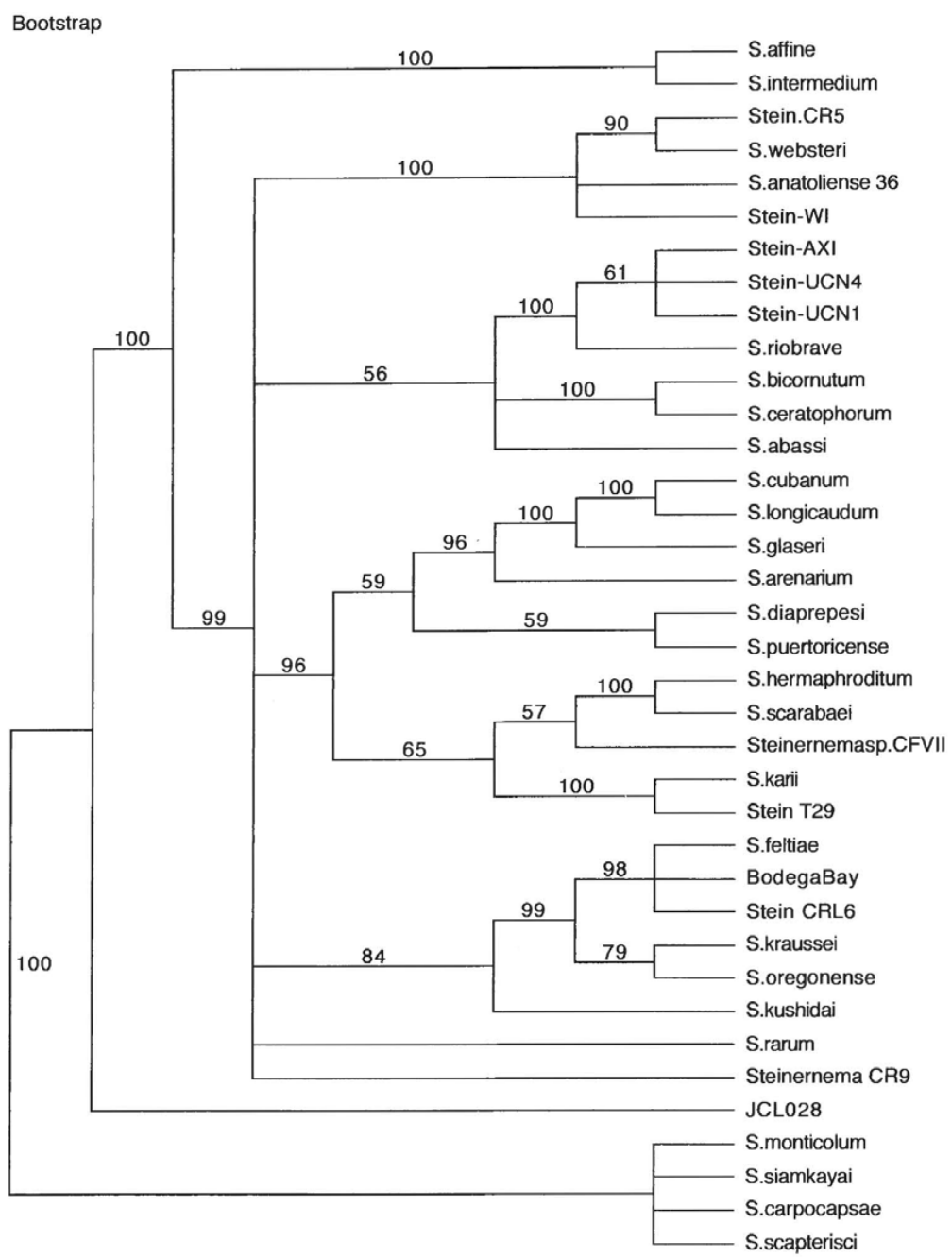

Figure 1:- Dendrogrammthat shows the species philogenyfor the genresSteinernema sp. and native isolatesSteinernema sp AN1, Steinernema sp AN3 and Steinernema sp AN4

\section{Literature:-}

1. Alves, S. B. (1986). Patología General. En: Controle microbiano de insectos. (Ed.), (pp. 1-70, 137-277). Brazil: Manole.

2. Aquino, T., Ruiz, J. y Iparraguirre, M. (2006). Biological control of the black weevil (Scyphophorus interstitialis Gyllenhal) with Entomopathogenic nematodes and fungi in agave in Oaxaca, México. Revista Científica UDO Agrícola, 6 (1), 92-101.

3. Brown, I. M., y Gaugler, R. (1997). Temperature and humidity influence emergence and survival of entomopathogenic nematode. Nematologica, 43: 363-375.

4. Campbell, J. F., y Gaugler, R. (1997). Inter-specific variation in the entomopathogenic nematode foreign strategy: Dichotonomy or variation a continuum? Fundam. Appl. Nematol, 20: 393-398.

5. Cabanillas, E. H., Poinar, Jr. G. O. y Raulston, J. R. (1994a). Steinernema riobravis n. sp. (Rhadbitidae: Steinernematidae) from Texas. Fundam. Appl. Nematol, 17, 123-131.

6. Cabanillas, E. H. y Raulston, J. R. (1994b). Pathogenicity of Steinernema riobravis against corn earworm Helicoverpa zea (Boddie). Fundam. Appl. Nematol, 17, 219-223.

7. Cabanillas, E. H. (2003). Susceptibility of boll weevil to Steinernema riobrave and other entomopathogenic nematodes. J. Invertebr.. Pathol, 82, 188-197.

8. De Doucet, M. M. A. (1986). Técnica rápida para detectar nematodos entomófagos. Rev. Cs. Agropec, 5, 57-63. De Doucet, M. M. A. (1990). Steinernema ritteri sp. (Nematoda Steinernematidae) with a key to the species of the genus. 
Nematologica, 36, 257-265.

9. De Doucet, M. M., Bertolotti; A., Glayetto, A. L. y Miranda, M. B. (1999). Host range, specificity y virulence of Steinernema feltiae, Steinernema rarum, and H. bactiophora (Steinernematidae and Heterorhabditidae) from Argentina. J.Invertebr. Pathol, 73, 237- 242.

10. Epsky, N. D. y Capinera, J. L. (1994). Invasion efficiency as measure of efficacy of the entomogenous nematode Steinernema carpocapsae (Rhabditida: Steinernematidae). J. Econ. Entomol, 87, 366-370.

11. EPPO. (2002). European and Mediterranean Plant Protection Organization. http://www.eppo.org/QUARANTINE/Alert_List/Insects/scypat.html. (19/nov/2002).

12. Finney, D. J. (1971). Probit analysis. Cambridge: Cambridge University Press. Forschler, B. T. y Gardner, W. A. (1991). Field efficacy and persistence of Entomopathogenic nematode in the management of white grubs (Coleoptera: Scarabeidae) in turf and pasture. J. Econ. Entomol, 84, 1454-1459.

13. Gaugler, R. (1981). Biological control potential of Neoaplectanid nematodes. J. Nematol, 13, 241-249.

14. Gaugler, R. (1988). Ecological considerations in the biological control of soil inhabiting insects with entomopathogenic nematodes. Agric Ecosys Environ, 24, 351-360.

15. Gaugler, R., Campbell, F. J. y Mcguire T. R. (1990). Fitness of a genetically improved Entomopathogenic nematode. J. Inv. Pathol, 56, 106-116.

16. Gentry, H. S. (1982). Agaves of Continental North America. (p.670).Tucson, Arizona: University of Arizona Press.

17. Hillis, D. M. y Moritz, A. C. (1996). Molecular Systematics. $2^{\text {nd }}$ Edition. Sunderland: Mass. Associates.

18. Hopkinson, D. y Maseru, E. A. (1970). The Control of the Sisal weevil (Scyphophorus interstitialis Gyll. Curculionidae, Coleoptera) in Sisal in Tanzania. V-ways of reducing weevil attack. East African Agricultural and Forestry Journal. 35 (3), 286-290.

19. Kaya, H. K. (1990). Soil Ecology, En: Entomopathogenic Nematodos in Biological Control. Gaugler R. y Kaya, H. K. (Eds.). (pp. 93-115). Boca Raton, FL: CRC Press.

20. Kaya, H. K. y Gaugler, R. (1993). Entomopathogenic nematodes. Ann. Rev. Entomol, 38,181- 206.

21. Kaya, H. K. y S. P. Stock. (1997). Techniques in insect nematology: in: Manual of Techniques in insect pathology, L. A. Lacey (ed). Biological Techniques Series, (p. 281-324). San Diego, California: Academic Press.

22. Poinar, G. O. Jr. (1979). Nematodes for biological control of insects. Boca Raton, Fl. USA: CRC. Press.

23. Poinar, G. O. Jr. (1990). Taxonomy and biology of Steinernematidae and Heterorhabditidae. En: Entomophatogenic Nematodes in Biological Control.

24. Reid, A. P., Hominick, W. M. (1992). Restriction fragment length polymorphisms within ribosomal DNA repeat unit of British Entomopathogenic nematodes (Rhabditida: Steinernematidae). Parasitology, 105, 317-323.

25. Reid, A. P., Hominick, W. M. y Briscoe, B. R. (1997). Molecular taxonomy and phylogeny of entomopathogenic nematode species (Rhabditidae: Steinernematidae) by RFLP analysis of the ITS region of the ribosomal DNA repeat unit. Syst. Parasitol., 37, 187- 193.

26. Ricci, M., Glazer, I., Campbell, J. F. y Gaugler, R. (1996). Comparison of Bioassays to Measure Virulence of Different Entomopathogenic Nematodes. Biocontrol Sci. Technol., 6, 235-245.

27. Shapiro, D. I., Berry, E. C., y Lewis, L.C. (1993). Interactions between Nematodes and Earthworms: Enhanced Dispersal of Steinernema carpocapsae. J. Nematol, 25(2), 189- 192.

28. Simoes, N., y Rosa, J. S. (1996). Pathogenicity and host specifity of Entomopathogenic nematodes. Biocontrol Sci.Technol., 6, 406-411.

29. Solís, A. J. F., González, H. H., Leyva, V. J. L., Equihua, M. A., Flores, M.F.J., y Martinez, G. A. (2001). Scyphophorus acupunctatus Gyllenhal, Plaga del agave tequilero en Jalisco, México. Agrociencia, 35, 663-670.

30. Stock, S. P.; Campbell, J. F. y Nadler, S. A. (2001). Phylogeny of Steinernema travassos, 1927 (Cephalobina: Steinernematidae) inferred from ribosomal DNA sequences and morphological characters. J. Parasitol, 87. 877-889.

31. Valdés, E. M. E. (2002). Manejo Integrado de Scyphophorus acupunctatus (Coleoptera: Curculionidae) en nardo y agave en el Estado de Morelos. En http://www.ceprobi.ipn.mx/Proyectos/cgpi/penotmologia/nardo.htm. 07/nov/2002.

32. Velázquez J., Joly J. L., García J. L., Romer Y., González M., MedinaM. (2006). Enemigos naturales del "Picudo del Agave" Scyphophorus acupunctatus Gyllenhal (Coleoptera: Curculionidae) en el Estado Falcón, Venezuela. ENTOMOTROPICA Vol. 21(3): 185-193.

33. Valenzuela, Z. A. G. (1997). El Agave Tequilero: su Cultivo e Industria. (Ed). (pp.17-193), Lítteris.

34. White, G. F. (1927). A method for obtaining infective nematode larvae from cultures. Science, 66, 302-303.

35. Wilson, M. J., Glen, D. M., Hughes, L.A., Pearce, D. J. y Rodgers, P. B. (1994). Laboratory Tests of the Potential of Entomopathogenic Nematodes for the control of field slugs (Deroceras reticulatum). J. Invertebr. Pathol, 64, $182-187$.

36. Woodring, J. L. y Kaya, H. K. (1988). Steinernematid and Heterorhabditid Nematodes: A Handbook of Techniques. (Pp.13-16), Southern Cooperative Series Bulletin, 331, Fayeteville, Arkansas, E.U.A: 